\title{
Upgrading and the geography of the Hungarian automotive industry in the context of the fourth industrial revolution
}

\author{
ERNô MOLNÁR ${ }^{1}$, GÁbor KOZMA ${ }^{1}$, MÁrk MÉSZÁROS ${ }^{1}$ and Éva KISS²
}

\begin{abstract}
The present study focuses on the geographical investigation of the automotive industry in Hungary that has been integrated into the global production networks as a relevant sector of the reindustrialization in EastCentral Europe. The aim of the paper is to reveal the dominant spatial trends in this sector since the economic crisis of 2008, and how these are connected to the issue of upgrading influenced also by digitalization. The analysis is primarily based on the official industrial employment data however other secondary sources are also used. It has been stated that the growth of the Hungarian automotive industry showing to the direction of geographical concentration and expansion is accompanied by the regional stability of the sector. Quality indicators expressing upgrading indicate correlation with the spatiality of car factories and Tier 1 suppliers carrying out more complex activities, but a more significant functional upgrading is only realised in the capital city with increasingly research-development focused profile. Results suggest only moderate upgrading despite the gradual adaptation of Industry 4.0 technologies.
\end{abstract}

Keywords: Industry 4.0, upgrading, automotive industry, geography, Hungary.

Received November 2019, Accepted April 2020.

\section{Introduction}

It is expected that the "fourth industrial revolution" based on the combined application of various key-innovations, the so called cyberphysical systems (CPS) will drastically transform current production networks and thus the geography of industry (Boston Consulting Group, 2015). Such changes may affect deeply the automotive industry that became an important sector of the East-Central European economies over the last three decades. Countries relying on foreign direct investments, following an export-oriented growth model and treating the automotive industry as a strategic sector have increasingly significant roles in the international production networks of the sector (Sснамг, E.W. 2005;
Pavlínek, P. et al. 2017). In certain countries vehicle production has a great impact even on the spatial structure of manufacturing industry and in this way, for example in Hungary, it has an important role in shaping spatial economic inequalities (KIss, É. 2010; Lengyel, I. and VArga, A. 2018). As a result, the future of the automotive industry is also the question of general modernization and regional development.

Although the innovations of the fourth industrial revolution are already present in Hungary, the volume of changes is hard to estimate due to the lack of comprehensive analyses. Furthermore, the boundaries of Industry 4.0 are flexible: technological innovations occur not as the result of an overwhelming revolutionary transformation, but rather

\footnotetext{
${ }^{1}$ University of Debrecen, H-4032 Debrecen, Egyetem tér 1. Hungary. E-mails: molnar.erno@science.unideb.hu, kozma.gabor@science.unideb.hu, mesmark94@gmail.com

${ }^{2}$ Geographical Institute, Research Centre for Astronomy and Earth Sciences. H-1112 Budapest, Budaörsi út. 45. Hungary; University of Sopron, Faculty of Economics, H-9400 Sopron, Erzsébet u. 9. Hungary.

E-mail: kiss.eva@csfk.mta.hu
} 
as the part of a gradual evolutionary process; their rationally selective adaptation depending on company demands and possibilities is typical (Szalavetz, A. 2016; Nagy, Cs. et al. 2020). The effects of the transformation are clear primarily in the increase of the production efficiency - related mostly to automation - in the Hungarian automotive industry that has predominantly a production function (Losonci, D. et al. 2019; Szalavetz, A. 2019). Nevertheless, certain innovations (modelling, simulation, uniform company software) help to establish functions beyond production, to share certain tasks with the centre and to specialize to partial tasks in some fields relevant from digitalization point of view (SzalaveTz, A. and Somosi, S. 2019).

At this point Industry 4.0 connects to the research of upgrading. In the case of semiperiphery economies like Hungary, upgrading - which means higher local value added - would be especially important in the change of position in the international production networks. This could be achieved by increasing the production efficiency, changing product structures and the functions in the production networks or by shifting towards more promising industries and value chains (Humphrey, J. and Schmitz, H. 2002; Kaplinsky, R. 2013). According to the global production network theory upgrading is essential to avoid exclusion from the production networks due to the increase of expenses (by keeping low cost-capability ratios) triggered by going beyond the role of cheap producer (Yeung, H.W. and Coe, N.M. 2015).

The role of the "fourth industrial revolution" shall not be regarded absolute, either from the future of the automotive industry or from the point of view of the upgrading perspectives of East-Central European economies. The geography of this sector is also greatly influenced by new products (e.g. electric, autonomous and connected cars, car sharing) and business models. These will influence not only the structure of value chains but also - depending on the involvement of info-communication companies playing an increasingly important role in the innova- tions of the automotive sector - who leads these networks (Peters, S. et al. 2016; YIN, Y. et al. 2018). Apart from the technology and the products, changes in trade regulations determining production organization and stricter environmental protection specifications influencing product development are also important factors (Dicken, P. 2011).

The present study focuses on the geographical investigation of the automotive industry in Hungary. The dominant regional trends since the economic crisis of 2008 are studied and their relationship with the process of upgrading influenced by digitalization as well. The study can be divided into four major structural units. In the first unit - based on the relevant literature background - the spatial structure of the automotive industry, its characteristics in East-Central Europe and in Hungary, and the relevant correlations with the fourth industrial revolution and upgrading are discussed. The second unit presents the database and methods of the empirical investigation in detail. Regional data are analysed in the third structural unit and the obtained results are interpreted in the fourth unit. The main contribution of this paper to the economic geography literature is that it reveals the connection between the way of participation in the international production networks and the geography of the automotive industry on case of Hungary.

\section{The geography of automotive industry reflecting Industry 4.0 and upgrading}

The automotive industry has a specific "nested structure" (Sturgeon, T. et al. 2008). Car companies and the major suppliers work mainly at a global scale while their production systems are organised either regionally or at the level of national economies. This phenomenon is the result of the different product preference of regional markets, logistical reasons and political pressure due to the "sensitivity" of the sector expecting cars assembled locally to use preferably locally manufactured parts. Those elements 
of the production networks that prefer cost efficiency move to the so called integrated peripheries (PAvlíneK, P. 2018) where they target regions close to the centre (e.g. the core regions of the EU) in both geographical and cultural sense offering appropriate infrastructural background and relatively welltrained labour. In this way, they can enjoy the closeness of markets and the possibility of favourable cost-value production (BARTA, Gr. 2012; Domański, B. et al. 2013).

Beside this tendency, the formation of local clusters within the above regional production systems can be observed. As platform concepts aiming for the partial standardization of products for different markets and economies of scale become widespread car producers require their suppliers to follow them to new markets (Humphrey, J. and Memedovic, O. 2003). Geographical closeness is especially advantageous for the manufacturers of large, heavy and model specific parts, not only saving logistic costs but facilitating just-intime supply and more flexible responses to customer demand. Spatial concentration is made even stronger by the modularization of production (TúRY, G. 2017). In the course of modularization, the car is assembled using pre-assembled modules making the establishment of pre-assembly plants and supplier parks next to the automobile factories. As suppliers are also interested in the development of component parts and modules, they move next to automobile factories because direct communication between them is possible in this way in the course of joint developments (StURGeON, T. et al. 2008).

The above regional and local site selection strategies resulted in the development of an automotive agglomeration (Grosz, A. 2006; Pavlínek, P. et al. 2009) identified in EastCentral Europe extending over the neighbouring areas of Czechia, Slovakia, Poland and Hungary crossing the borders of national economies. This concentration of the automotive industry can be explained by - apart from the already discussed factors - historical traditions (HARDI, T. 2012), multistage investments of car companies entering the region after the regime change and gradually increasing degree of intra-regional division of labour (Molnár, E. et al. 2015). Although the recent economic crisis had its effects on the automotive industry of the region (KIss, É. 2012), its position - despite the partial relocation of the more labour-intensive activities - strengthened (PavlíneK, P. et al. 2017). Upgrading in the East-Central European automotive industry also had its role in achieving this better position. However, the realisation of this upgrading seems to be regarding especially the functional elements - limited (Jürgens, U. and Krzywdzinski, M. 2011; Éltető, A. et al. 2015; PAvlíneK, P. 2018).

According to certain scenarios, the "fourth industrial revolution" may question the role of the East-Central European region in the international production networks. While experience so far does not justify negative expectations, analysts see the state of "the calm before the storm" in the situation (SzALAVETz, A. and Somosi, S. 2019). Despite the effects of Industry 4.0 innovations on upgrading the gap between value production by foreign parent companies and that by local subsidiaries does not seem to be reduced (Szalavetz, A. 2019). This supports the suspicion that technological innovations cement core-periphery relations (LENGYEL, I. et al. 2016).

Analyses focus very little on the local effects of Industry 4.0. However, there is a suggestion that the adaptation of innovations is influenced by the dual character of the Hungarian industry. Certain industries (including automotive manufacturing), large companies and businesses with foreign ownership (i.e. actors with better resource supply) are ahead in the process. Their unequal spatial distribution also influences the geography of the adaptation of innovations in Hungary (Nick, G. et al. 2019). The applications of new technologies take place gradually and this means primarily the development of existing capacities instead of building new factories (Szalavetz, A. 2016). Finally, according to some opinions, Industry 4.0 appreciates locally available competent suppliers: in changing circumstances not for- 
eign investments bring a technological catchup, but the technological catch-up of local businesses generates foreign investments (Szalavetz, A. and Somosi, S. 2019). These ideas indicate the important role of quality location choice factors that are difficult to reproduce and of local or regional clusters with a significant history even in the age of Industry 4.0.

The role of local clusters in upgrading is explained by the idea of "dynamic strategic coupling" in the global production network concept. According to this, the development of a region is the result of successful global local interactions influenced at a local scale by the concentration of knowledge, abilities and experience in the industry (economies of scale), and by co-operation and learning possibilities (economies of scope) (CoE, N.M. and Hess, M. 2011). The regional institutional background is important in the coupling process and it can be regarded as the derivate of national and supranational actors that is specific to the location. Institutes can steer upgrading forward with strengthening local factors while local factors showing greater complementarity with the demands of companies controlling production networks strengthen the position of regional institutes against global actors (Coe, N.M. et al. 2004). Accordingly, the East-Central European automotive cluster presented earlier - based on local synergies - has relatively advantageous chances for upgrading (PAvlíneK, P. et al. 2009).

The analysis of the relationship between spatial concentrations and upgrading occurs in several papers on automotive industry. In the case of the supplier network of the Czech Skoda, for example, simultaneous spatial expansion and concentration were observed. While low cost and excessive labour are offered in the periphery, quality location factors dominate in the traditional core areas. The development of spatial concentrations is driven by increasing interdependence of automobile factories and suppliers due to modularization, just-in-time organisation of supply, reducing logistic costs and service requirements for the products that can be sat- isfied easier from closer areas (PAvLÍneK, P. and JANÁK, L. 2007). According to experience from Poland, the embedding of automobile manufacturers and their shift towards products with higher value added, i.e. upgrading results in the rise of spatial agglomerations. In the development of the largest concentration in Upper Silesia, for example, historical traditions, establishment of automobile factories as focus points in the neighbouring Czech and Slovakian regions, the concentration of part factories, the local possibilities of research and development and higher education together with the concentration of industry and population all had a major role; and they provided greater resistance for the region at the time of the crisis (GwosDz, K. and Мiсек, G. 2010; DoмAŃski, B. et al. 2013).

The spatial structure of the Hungarian automotive industry with no automobile manufacturing traditions and supplier network prior to the regime change (in contrast to the Czech or Polish examples) can be explained by the importance of geographical location close to the western regions, industrial traditions associated with commercial vehicle production (skilled labour) and well-established infrastructure (motorways, industrial parks) (BARTA, Gy. 2002; Kiss, É. and Tiner, T. 2012). The retaining strength of industrial concentrations is suggested by the regional stability of the automotive industry and also by its decreasing and increasing spatial concentration at the time of growth and recession respectively (Molnár, E. 2013). The process of embedding - interpreted initially via the development of the local supplier network and then in a much more complex way - received significant attention due to the dominance of the greenfield investments of large foreign companies (SASS, M. and SzANYI, M. 2004; Fekete, D. and Rechnitzer, J. 2019). The relationship between embedding and upgrading occur in the strategy of the major companies in the automotive industry established in Hungary following the turn of the millennium that accelerate their embedding in order to create the local atmosphere required for upgrading sooner (JózsA, V. 2019). 
The automotive industry - due to its size and extensive industrial connections - leaves its mark on the geography of the entire Hungarian industry. Micro- and macro-scale radical changes, the strong differentiation of the spatial dynamics of the industry were in the background of the drastic transformation at the time of the regime change (KISS, É. 2002; Nemes Nagy, J. and Lốcsei, H. 2015). The dominance of the north-western part of the country and that of the agglomeration around the capital became general; however, this seems to ease somewhat as a consequence of the reindustrialization - partly due to automotive investments - of certain counties in North Hungary and the Great Plain after 2008 (BARTA, Gy. 2002; Kiss, É. 2010; Lux, G. 2017).

The inclination of the automotive industry to form clusters at the local level, the quality factors of selecting site location associated with the spatial concentrations of the sector and relevant upgrading (and Industry 4.0), and the experience that the geographical transformations of the industry reflect the structural changes of those involved form the theoretical basis of the present spatial research at the subnational level.

\section{Database and methods}

Industrial employment data necessary for the county level (NUTS 3) analysis were provided by Hungarian Central Statistical Office. The 20 units (the capital city and 19 counties) allow only a general regional analysis, but no more detailed time series data are available. It has to be noted that, although the interpretation of counties as industrial geographical units always raises questions, the use of county data has a well-established practice. Officially, counties are classified into seven regions (NUTS 2 level) in Hungary. But, in this study the regional division of counties follows the historical traditions of Hungarian industry and the location choice of the automotive firms.

Employment data were chosen primarily because they are suitable for structural analy- ses. Linking the geography of the automotive industry to the issue of upgrading influenced by Industry 4.0 makes it necessary to focus on indices reflecting structural changes. For this the number of non-manual workers and average gross earnings of those working in the sector were used. A higher proportion of non-manual workers suggest the lower significance of labour-intensive physical activities, increasing automation of production and also the significant role of research and development, logistics and other strategic functions beyond direct production (Szalavetz, A. and Somosi, S. 2019). As different activity structures may be behind the data on the employment of manual and non-manual workers, ratios of average gross earnings relative to the national industry and local economic average were also analysed. It was presumed that the differences of the indicator reflect not only the labour market differences of the counties but also the structure of automotive industrial activities. To ground spatial research at the subnational level by investigating the effects of technological innovations on employment data is not without history in Hungary (То́тн, I.J. et al. 2016).

At the same time, a number of factors make it difficult to accurately outline the spatial footprint of the automotive industry. One of the factors is that the activities classified in the statistical category of motor vehicle industry do not cover the entire automotive industry because of the wide range of suppliers integrated into its value chains. Approximately there are 480 operating companies and more than 100,000 employees in the motor vehicle industry, but according to another source there is 900 companies and 175,000 employees (MAGE 2020). The latter numbers also include the automotive suppliers registered in other industries. At the same time, the aggregation of employment data at the sector level makes it impossible to systematically filter out suppliers outside the motor vehicle industry, therefore the present analysis was made using the smaller data that could be clearly assigned to the automotive industry. As a result, the present analysis can be applied primarily to the 'up- 
per regions' of the supplier pyramids dominated by transnational companies. However, focusing on the structural changes, this limitation - due to the uneven distribution of value-added in the supplier pyramid and the producer-driven character of the value chain - can only slightly influence the validity of our findings. A characteristic feature of functional upgrading the development of local suppliers registered in other industries remains partly hidden.

Another problem is the fact that the industrial classification of companies considered along value chains varies in time. Consequently, there may be statistical reasons - in addition to real developments for the increase and decrease in data. Data register based on the headquarters of companies has a similar effect, which assigns the performance of companies present in some counties to the county designated as headquarters, showing its role as more significant than it is. When analysing employment data, the fact that the employment of temporary workers offered by specialized agencies became widespread in the studied period has to be addressed. The automotive industry employed the greatest number of temporary workers - 16,900 people - in 2018 (Pénzügyminisztérium 2019). In the light of the sector's statistics this not only means that they do not contain a large portion of temporary workers and the real significance of motor vehicle industry is underestimated, but also that in some counties temporary workers can also be the cause of reduced employment (not shrinking in fact) in automotive industry. Since the ratio of temporary workers is higher among manual workers, therefore this phenomenon also affects the indicators of employment structure.

In order to identify dominant spatial trends (concentration vs. expansion, differences in quantity and quality indices), simple spatial inequality indices (concentration index, Hoover index) were also calculated based on employment data. Changes in centres of gravity were also examined. In the analysis, employment data were com- plemented with other secondary sources. In addition to foreign trade statistics, the spatial data of economic organisations, data of investments supported by so called individual government decision, annual reports from certain companies and press releases on businesses in the industry were utilized. The timeframe for the research (2008-2018) is optimal for comparison not only because of the unchanged statistical framework of the industry, but it also enables the uniform analysis of the economic crisis, the recovery and then the new growth period together.

\section{Description of the spatial processes}

The long-term growth of employment in the motor vehicle industry in Hungary has only been temporarily disrupted by the economic crisis. The number of people employed fell by 18 per cent from 2008 to 2009 , only to increase again every year afterwards. Pre-crisis conditions were restored roughly in 2013, but taken as a whole there was a 35 per cent increase between 2008 and 2018. Although the county concentration of employment in the period of crisis and recovery was rather strengthened and then slightly weakened, the distribution of the automotive industry between regions is stable. The loss of significance of Central Hungary was offset by an increase in the share of three other regions. However, while in the first half of the period Northern Transdanubia was the winner of a moderate realignment, in recent years the share of Northern Hungary and the Great Plain could grow even at the expense of the former (Table 1).

The development trajectory of each county is more colourful. Between 2008 and 2013 half of the counties showed an increase in the employment of automotive industry while between 2013 and 201817 of the 20 spatial units. However, in almost a third of the counties - including Komárom-Esztergom and Pest - employment in the sector in 2018 did not come even close to the level of 2008. Apart from the rise of Győr-Moson-Sopron, the increasing number of counties with sig- 
Table 1. Number and share of employees in the Hungarian motor vehicle industry, 2008-2018

\begin{tabular}{|c|c|c|c|c|c|c|c|c|}
\hline \multirow{2}{*}{ Regions, counties } & \multicolumn{2}{|c|}{2008} & \multicolumn{2}{|c|}{2009} & \multicolumn{2}{|c|}{2013} & \multicolumn{2}{|c|}{2018} \\
\hline & Number & $\%$ & Number & $\%$ & Number & $\%$ & Number & $\%$ \\
\hline Central Hungary & 11,562 & 15.1 & 9,153 & 14.5 & 8,332 & 11.3 & 9,557 & 9.2 \\
\hline Budapest & 2,468 & 3.2 & 2,178 & 3.5 & 1,652 & 2.2 & 2,709 & 2.6 \\
\hline Pest & 9,094 & 11.9 & 6,975 & 11.1 & 6,680 & 9.0 & 6,848 & 6.6 \\
\hline Northern Transdanubia & 45,411 & 59.2 & 37,891 & 60.2 & 46,593 & 62.9 & 64,695 & 62.5 \\
\hline Fejér & 11,069 & 14.4 & 9,319 & 14.8 & 8,307 & 11.2 & 10,811 & 10.4 \\
\hline Győr-Moson-Sopron & 14,701 & 19.2 & 12,607 & 20.0 & 20,028 & 27.0 & 25,279 & 24.4 \\
\hline Komárom-Esztergom & 9,764 & 12.7 & 7,756 & 12.3 & 5,990 & 8.1 & 8,245 & 8.0 \\
\hline Vas & 5,364 & 7.0 & 4,724 & 7.5 & 6,536 & 8.8 & 8,974 & 8.7 \\
\hline Veszprém & 4,513 & 5.9 & 3,485 & 5.5 & 5,732 & 7.7 & 11,386 & 11.0 \\
\hline Southern Transdanubia & 2,711 & 3.5 & 2,132 & 3.4 & 3,350 & 4.5 & 3,748 & 3.6 \\
\hline Baranya & 891 & 1.2 & 626 & 1.0 & 980 & 1.3 & 1,189 & 1.1 \\
\hline Somogy & 202 & 0.3 & 242 & 0.4 & 304 & 0.4 & 239 & 0.2 \\
\hline Tolna & 539 & 0.7 & 399 & 0.6 & 741 & 1.0 & 1,002 & 1.0 \\
\hline Zala & 1,079 & 1.4 & 865 & 1.4 & 1,325 & 1.8 & 1,318 & 1.3 \\
\hline Northern Hungary & 9,433 & 12.3 & 7,765 & 12.3 & 8,328 & 11.2 & 14,139 & 13.7 \\
\hline Borsod-Abaúj-Zemplén & 3,457 & 4.5 & 3,099 & 4.9 & 5,768 & 7.8 & 9,237 & 8.9 \\
\hline Heves & 5,120 & 6.7 & 3,930 & 6.2 & 2,338 & 3.2 & 4,055 & 3.9 \\
\hline Nógrád & 856 & 1.1 & 736 & 1.2 & 222 & 0.3 & 847 & 0.8 \\
\hline Great Plain & 7,615 & 9.9 & 5,992 & 9.5 & 7,457 & 10.1 & 11,384 & 11.0 \\
\hline Bács-Kiskun & 2,477 & 3.2 & 1,967 & 3.1 & 5,358 & 7.2 & 9,142 & 8.8 \\
\hline Békés & 1,929 & 2.5 & 1,525 & 2.4 & 128 & 0.2 & 210 & 0.2 \\
\hline Csongrád & 392 & 0.5 & 298 & 0.5 & 143 & 0.2 & 205 & 0.2 \\
\hline Hajdú-Bihar & 218 & 0.3 & 191 & 0.3 & 210 & 0.3 & 286 & 0.3 \\
\hline Jász-Nagykun-Szolnok & 754 & 1.0 & 708 & 1.1 & 905 & 1.2 & 958 & 0.9 \\
\hline Szabolcs-Szatmár-Bereg & 1,845 & 2.4 & 1,303 & 2.1 & 713 & 1.0 & 583 & 0.6 \\
\hline Hungary total & 76,732 & 100.0 & 62,933 & 100.0 & 74,060 & 100.0 & 103,523 & 100.0 \\
\hline
\end{tabular}

Source: Central Statistical Office, Budapest, 2019.

nificant employment in automotive industry can be observed. Two of the newly emerging counties are east of the Danube: Bács-Kiskun and Borsod-Abaúj-Zemplén, however, have an increasing ratio of employment in the automotive industry in their region (Figure 1 and 2).

The change in the number of non-manual workers mostly followed the indicators of the total number of employees. The ratio of non-manual workers increased almost continuously and approached the average of the manufacturing industry. The spatial concentration of non-manual workers remained always below the index calculated for the total number of employees, while differences in the distribution of non-manual and manual workers decreased. Most non-manual workers are related to the automotive industry of GyörMoson-Sopron, Fejér and the rapidly growing
Veszprém county. Apart from the latter, only Budapest and some eastern counties showed ratios of non-manual workers characteristically above the national average (Table 2).

In counties with the largest expansion of employment in the automotive industry, the ratio of non-manual workers increased only slightly. This suggests that the growth of this sector remains mainly linked to the deployment of production capacities requiring primarily manual workers. Labour hire registered not in the automotive industry may also contribute to the above trends. It also causes, on the one hand a more modest increase of employment in the automotive industry, and on the other hand a higher ratio of non-manual workers. Significant differences among the counties indicate internal structural differences in the sector. Budapest pulled from the rest of the counties from 2017 to 2018, however, 


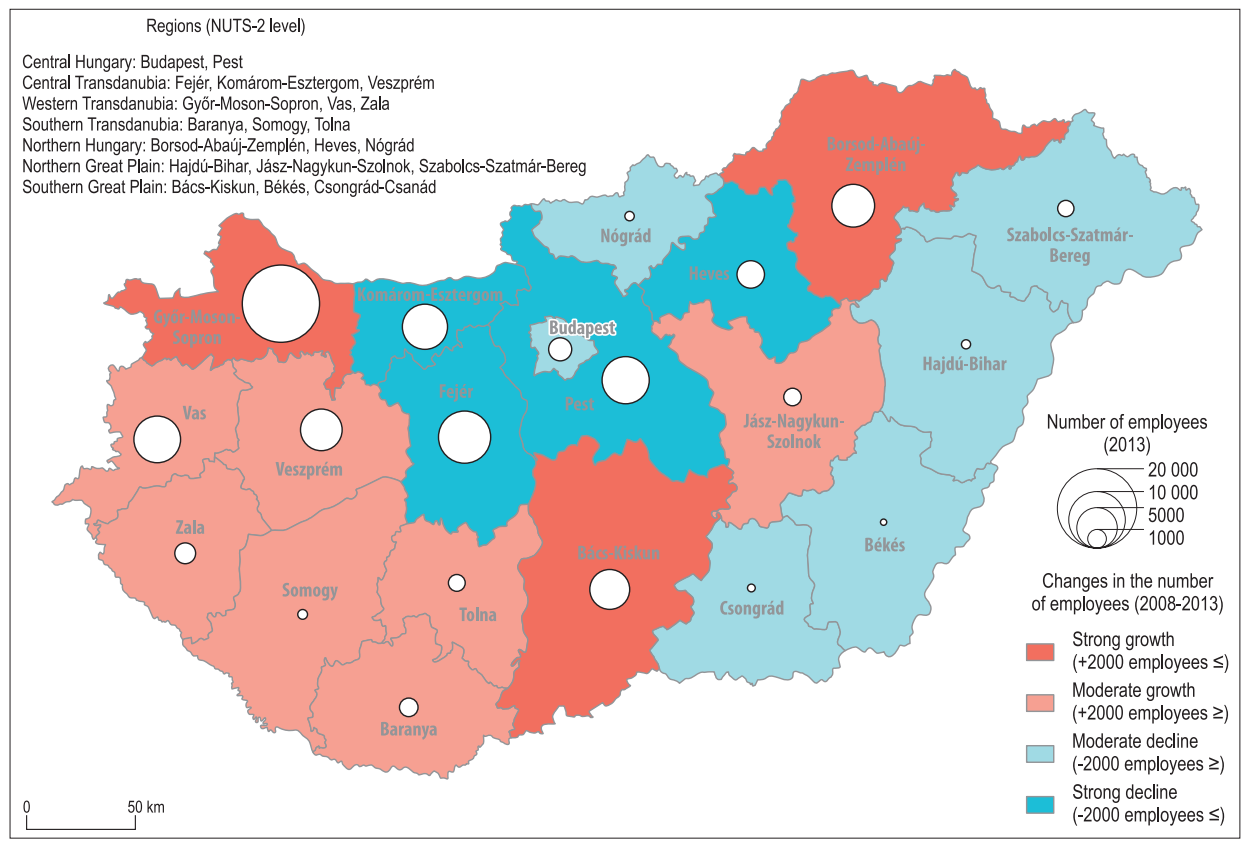

Fig. 1. Dynamics of the Hungarian automotive industry by the number of employees between 2008 and 2013 and its state in 2013. Source: Data of Central Statistical Office.

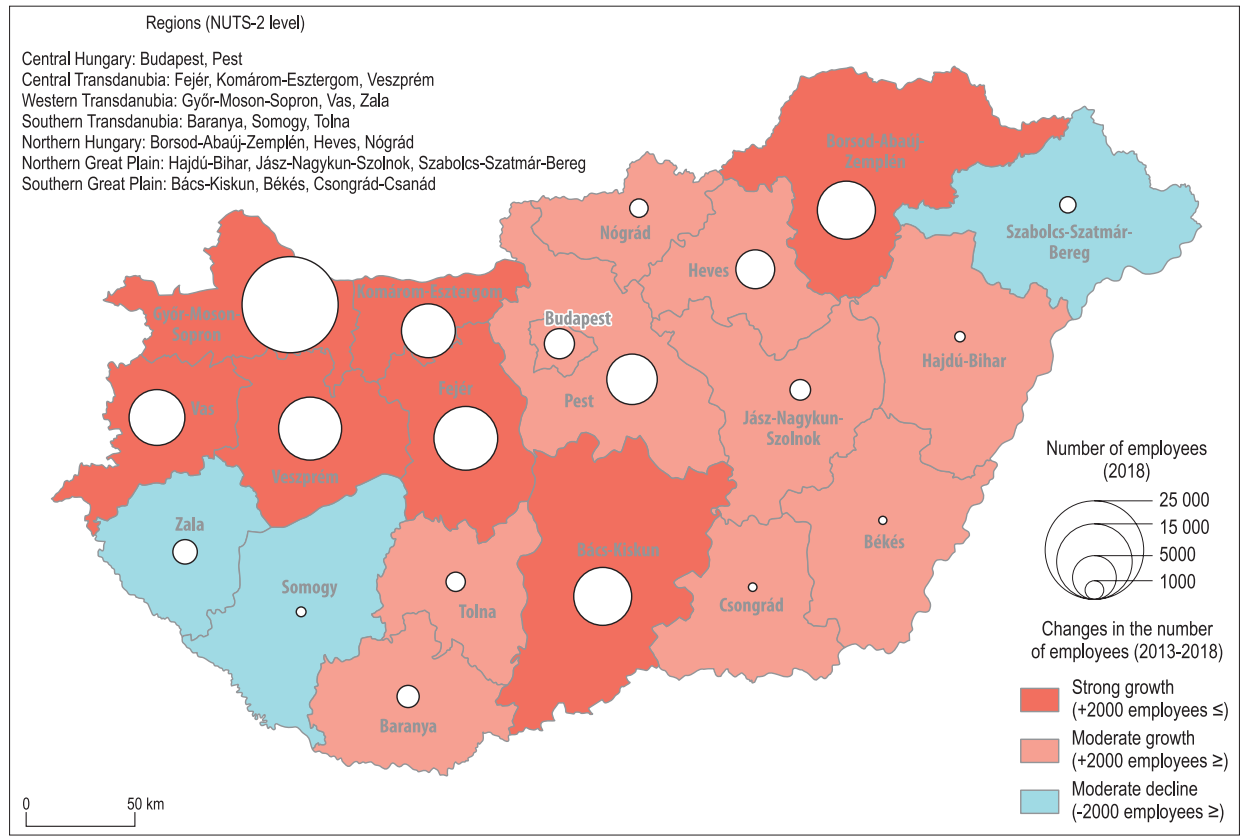

Fig. 2. Dynamics of the Hungarian automotive industry by the number of employees between 2013 and 2018 and its state in 2018. Source: Data of Central Statistical Office. 
Table 2. Number and share of non-manual employees in the Hungarian motor vehicle industry, 2008-2018

\begin{tabular}{|c|c|c|c|c|c|c|c|c|}
\hline \multirow{2}{*}{ Regions, counties } & \multicolumn{2}{|c|}{2008} & \multicolumn{2}{|c|}{2009} & \multicolumn{2}{|c|}{2013} & \multicolumn{2}{|c|}{2018} \\
\hline & Number & $\%$ & Number & $\%$ & Number & $\%$ & Number & $\%$ \\
\hline Central Hungary & 1,822 & 15.8 & 1,647 & 18.0 & 1,779 & 21.4 & 2,987 & 31.3 \\
\hline Budapest & 509 & 20.6 & 498 & 22.9 & 464 & 28.1 & 1,294 & 47.8 \\
\hline Pest & 1,313 & 14.4 & 1,149 & 16.5 & 1,315 & 19.7 & 1,693 & 24.7 \\
\hline Northern Transdanubia & 8,176 & 18.0 & 7,713 & 20.4 & 10,804 & 23.2 & 16,433 & 25.4 \\
\hline Fejér & 2,016 & 18.2 & 1,843 & 19.8 & 2,150 & 25.9 & 3,085 & 28.5 \\
\hline Győr-Moson-Sopron & 2,937 & 20.0 & 2,723 & 216 & 4,236 & 21.2 & 5,867 & 23.2 \\
\hline Komárom-Esztergom & 1,323 & 13.5 & 1,378 & 17.8 & 1,500 & 25.0 & 2,379 & 28.9 \\
\hline Vas & 930 & 17.3 & 896 & 19.0 & 1,323 & 20.2 & 1,970 & 22.0 \\
\hline Veszprém & 970 & 21.5 & 873 & 25.1 & 1,595 & 27.8 & 3,132 & 27.5 \\
\hline Southern Transdanubia & 359 & 13.2 & 316 & 14.8 & 502 & 15.0 & 600 & 16.0 \\
\hline Baranya & 155 & 17.4 & 131 & 20.9 & 177 & 18.1 & 204 & 17.2 \\
\hline Somogy & 35 & 17.3 & 34 & 14.0 & 49 & 16.1 & 24 & 10.0 \\
\hline Tolna & 72 & 13.4 & 59 & 14.8 & 138 & 18.6 & 192 & 19.2 \\
\hline Zala & 97 & 9.0 & 92 & 10.6 & 138 & 10.4 & 180 & 13.7 \\
\hline Northern Hungary & 2,332 & 24.7 & 2,109 & 27.2 & 2,061 & 24.7 & 3,805 & 26.9 \\
\hline Borsod-Abaúj-Zemplén & 840 & 24.3 & 835 & 26.9 & 1,276 & 22.1 & 2,337 & 25.3 \\
\hline Heves & 1,254 & 24.5 & 1,054 & 26.8 & 731 & 31.3 & 1,314 & 32.4 \\
\hline Nógrád & 238 & 27.8 & 220 & 29.9 & 54 & 24.3 & 154 & 18.2 \\
\hline Great Plain & 1,516 & 19.9 & 1,352 & 22.6 & 1,860 & 24.9 & 2,831 & 24.9 \\
\hline Bács-Kiskun & 657 & 26.5 & 554 & 28.2 & 1,413 & 26.4 & 2,317 & 25.3 \\
\hline Békés & 433 & 22.4 & 390 & 25.6 & 42 & 32.8 & 66 & 31.4 \\
\hline Csongrád & 49 & 12.5 & 38 & 12.8 & 37 & 25.9 & 53 & 25.9 \\
\hline Hajdú-Bihar & 47 & 21.6 & 47 & 24.6 & 47 & 22.4 & 68 & 23.8 \\
\hline Jász-Nagykun-Szolnok & 169 & 22.4 & 171 & 24.2 & 196 & 21.7 & 223 & 23.3 \\
\hline Szabolcs-Szatmár-Bereg & 161 & 8.7 & 152 & 11.7 & 125 & 17.5 & 104 & 17.8 \\
\hline Hungary total & 14,205 & 18.5 & 13,137 & 20.9 & 17,006 & 23.0 & 26,656 & 25.7 \\
\hline
\end{tabular}

Source: Central Statistical Office, Budapest, 2019.

the increase in the rate of non-manual workers was accompanied by a sharp decline in the number of people employed in the sector.

Average gross earnings recorded in the motor vehicle industry showed a significant increase with values above the national average throughout the studied period. The spatial concentration of gross earnings exceeded that of the employees, while the differences in the spatial distribution of employed people and gross earnings decreased. Counties are polarized: solely the front-runner GyörMoson-Sopron performed always above the industrial average. Regarding the counties with high employment growth, Veszprém was also able to achieve relative average gross earnings growth. Although average gross earnings also depend on the local labour market environment, it is notable that the figures of counties outstanding from the national average of the motor vehicle industry - with the exception of Budapest - also showed the highest difference compared to local average earnings (Table 3).

As a summary, it can be concluded that, between 2008 and 2018, on the one hand, the number of counties standing out in relation to at least one of the analysed indicators (share of non-manual workers, average gross earnings) was reduced, and, on the other hand, showed greater overlap with the major locations of the sector (Figure 3 and 4).

Not only the industry as a whole, but also its qualitative indicators show increasing spatial concentrations only during the period of crisis and recovery, while differences in the distribution of qualitative and quantitative indicators decrease. As a consequence there is a geographical convergence regarding the (quantity and) quality factors (Figure 5 and 6). 
Table 3. Average gross earnings of employees in the Hungarian motor vehicle industry in percentage of the sector's average and the average of the given area's economy, 2008-2018

\begin{tabular}{|c|c|c|c|c|c|c|c|c|}
\hline \multirow{2}{*}{ Regions, counties } & \multicolumn{2}{|c|}{2008} & \multicolumn{2}{|c|}{2009} & \multicolumn{2}{|c|}{2013} & \multicolumn{2}{|c|}{2018} \\
\hline & NAS $\%$ & GAE\% & NAS $\%$ & GAE\% & NAS $\%$ & GAE $\%$ & NAS $\%$ & GAE \% \\
\hline Central Hungary & 92 & 82 & 91 & 83 & 85 & 89 & 95 & 100 \\
\hline Budapest & 103 & 85 & 105 & 89 & 75 & 75 & 108 & 107 \\
\hline Pest & 89 & 108 & 88 & 108 & 87 & 119 & 90 & 123 \\
\hline Northern Transdanubia & 106 & 128 & 107 & 132 & 108 & 144 & 107 & 137 \\
\hline Fejér & 84 & 98 & 83 & 102 & 85 & 112 & 88 & 112 \\
\hline Győr-Moson-Sopron & 126 & 145 & 132 & 156 & 126 & 156 & 123 & 148 \\
\hline Komárom-Esztergom & 109 & 126 & 105 & 123 & 98 & 125 & 97 & 123 \\
\hline Vas & 112 & 146 & 104 & 140 & 102 & 146 & 100 & 135 \\
\hline Veszprém & 85 & 112 & 94 & 128 & 101 & 150 & 102 & 141 \\
\hline Southern Transdanubia & 58 & 75 & 56 & 76 & 58 & 90 & 62 & 93 \\
\hline Baranya & 74 & 91 & 71 & 93 & 65 & 100 & 66 & 101 \\
\hline Somogy & 60 & 82 & 60 & 86 & 60 & 95 & 64 & 96 \\
\hline Tolna & 59 & 74 & 58 & 74 & 63 & 88 & 62 & 84 \\
\hline Zala & 44 & 61 & 43 & 61 & 51 & 82 & 58 & 92 \\
\hline Northern Hungary & 106 & 136 & 101 & 135 & 91 & 142 & 88 & 132 \\
\hline Borsod-Abaúj-Zemplén & 84 & 109 & 83 & 113 & 85 & 138 & 84 & 132 \\
\hline Heves & 124 & 149 & 118 & 146 & 109 & 149 & 100 & 135 \\
\hline Nógrád & 84 & 116 & 79 & 115 & 60 & 103 & 62 & 100 \\
\hline Great Plain & 83 & 112 & 84 & 119 & 93 & 151 & 93 & 144 \\
\hline Bács-Kiskun & 112 & 154 & 113 & 161 & 99 & 156 & 97 & 142 \\
\hline Békés & 77 & 108 & 78 & 114 & 85 & 148 & 70 & 118 \\
\hline Csongrád & 56 & 73 & 55 & 73 & 72 & 110 & 74 & 107 \\
\hline Hajdú-Bihar & 62 & 81 & 63 & 84 & 65 & 101 & 66 & 100 \\
\hline Jász-Nagykun-Szolnok & 96 & 134 & 95 & 140 & 82 & 133 & 86 & 131 \\
\hline Szabolcs-Szatmár-Bereg & 51 & 71 & 55 & 81 & 76 & 132 & 61 & 108 \\
\hline Hungary total & 100 & 107 & 100 & 110 & 100 & 126 & 100 & 124 \\
\hline
\end{tabular}

Notes: NAS $\%=$ in percentage of the sector's (motor vehicle industry) average. GAE $\%=$ in percentage of the average of the given area's (county, region) economy. Source: Central Statistical Office, Budapest, 2019.

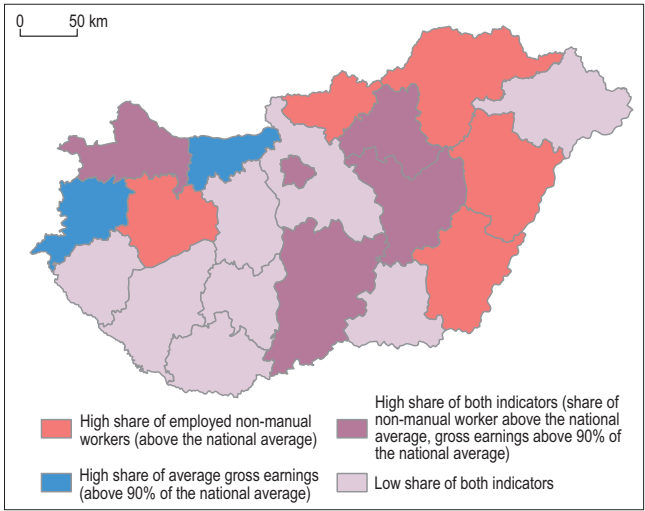

Fig. 3. Types of counties by share of non-manual workers and average gross earnings in the Hungarian motor vehicle industry, 2008. Source: Data of Central Statistical Office.

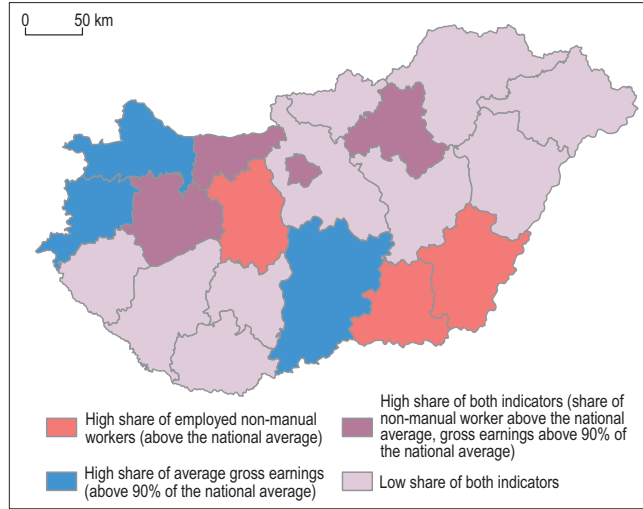

Fig. 4. Types of counties by share of non-manual workers and average gross earnings in the Hungarian motor vehicle industry, 2018. Source: Data of Central Statistical Office. 


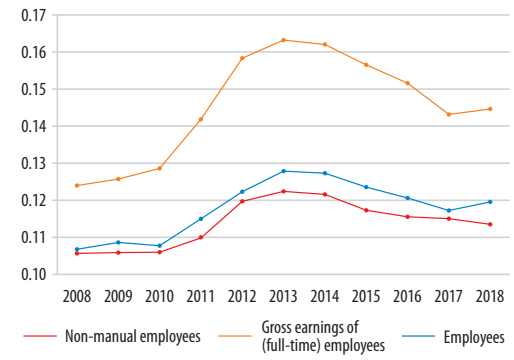

Fig. 5. Concentration indices of the analysed indicators. Source: Data of Central Statistical Office.

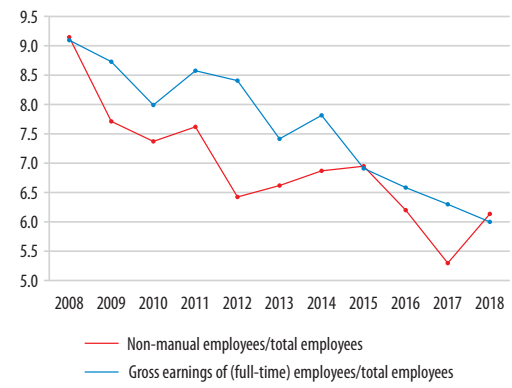

Fig. 6. Hoover indices of the qualitative indicators and the total number of employees. Source: Data of Central Statistical Office.

According to our calculations the location of the centres of gravity of the studied indicators is in the central part of Transdanubia. The indicators also show a typically westward shift between 2008 and 2018. The centres of gravity of non-manual employment can be found further east, while those of the gross earnings are further north-west compared to the number of people employed (Figure 7).

The results declined that - despite the strengthening of some eastern "bridgeheads" - a significant eastern shift in the Hungarian automotive industry would have taken place. The impact of Budapest and some betterperforming eastern counties on non-manual employment as well as the effect of Northern Transdanubia showing higher average values in the spatiality of earnings are also accentuated. The position of the centres of gravity also reflects the recurrence of the traditional NorthSouth differences of Hungarian industry.

\section{Explanation of the spatial processes}

The geography of the Hungarian motor vehicle industry reflects the location decision of foreign companies and - to a much lesser extent - the spatiality of the emerging domestic automotive industrial suppliers. 97 per cent of the turnover in the sector can be related to foreign-controlled companies, and this is well above the national average of 53 per cent and one of the highest in the manufacturing industry (KSH, 2016). The expansion of the employment in the automotive industry indicates that Hungary remains an investment destination, and the negative expectations associated with the spread of Industry 4.0 innovations do not appear to be confirmed during the studied period. Automation has not caused a decrease: even if some of the workforce was liberated due to technological reasons, it is mostly redeployed within the firms in "headcount neutral transformation", because capacity expansion is still common. The progress of automation is delayed partly, because foreign workers are employed in order to ease labour shortage (SzÉKELY, S. 2019).

The vast majority of the sector's employment growth is attributable to some prominent companies in five counties. These are mostly foreign-owned subsidiaries established before 2008, whose multi-stage investments play a decisive role in the stability of the space structure of the Hungarian automotive industry (Table 4).

However, the success of these subsidiaries in the competition for new investments can only be partly explained by technologicallybased improvements in cost-capability ratios even in ideal cases. Government support may have also contributed to their success. The most spectacular example of new developments on old sites is the functional upgrading of Audi's factory, where the car assembly plant was transformed into a full car production plant (including stamping plant, car body factory and paint shop) - with the relocation of activities from Germany - employing thousands of people. The growth of a company however was not always linked only to loca- 


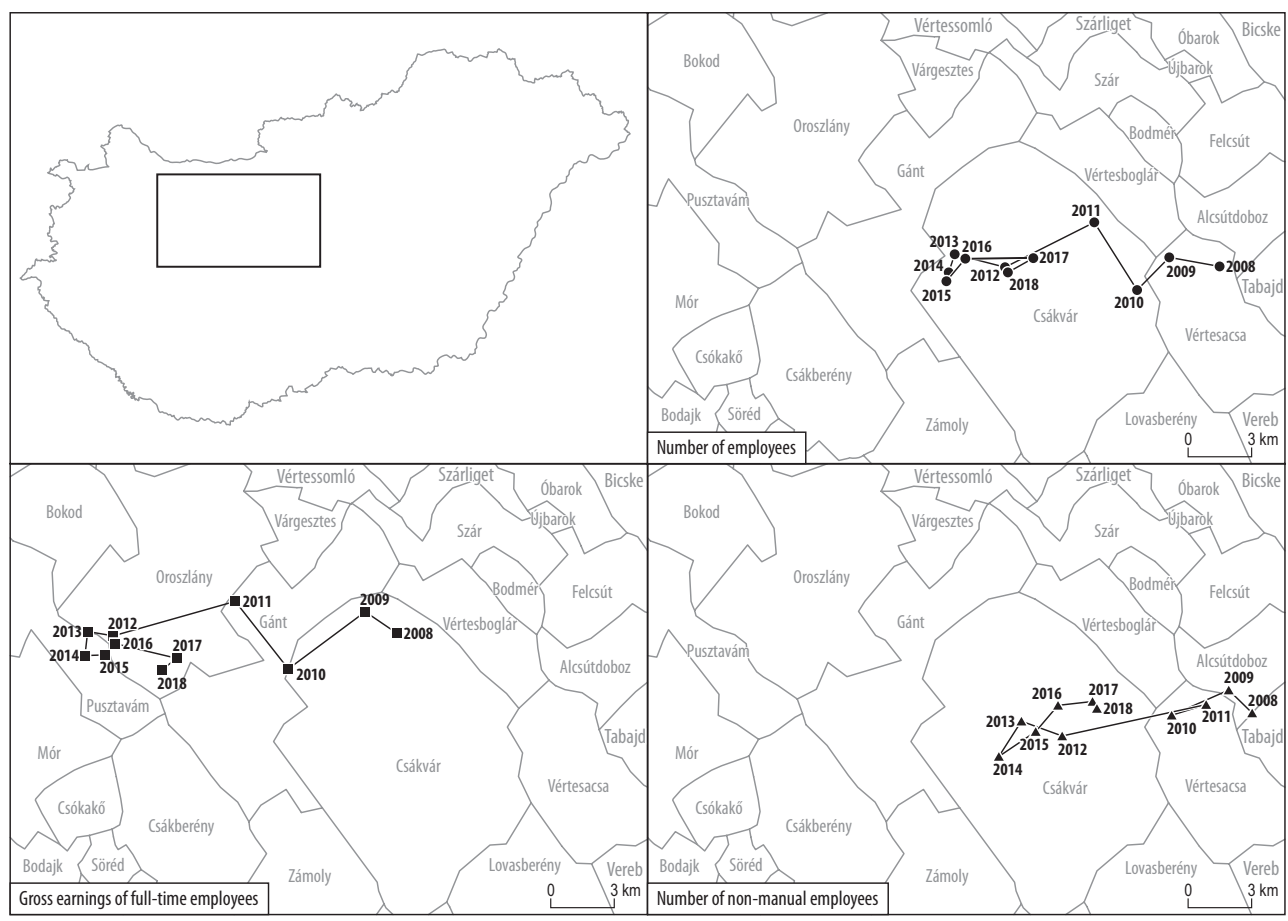

Fig. 7. Changes in the centres of gravity regarding the studied indicators of the Hungarian motor vehicle industry. Source: Data of Central Statistical Office.

tions within the priority counties. For example, hundreds of employees were employed at the newly established and purchased sites (in the Great Plain) of SMR Automotive Mirror Technology headquartered in Györ-MosonSopron county and nearly 1,500 employees were employed at the Budapest unit of the Continental subsidiary located in Veszprém county in 2018. In fact, data suggesting spatial concentrations mask geographical expansion in the case of Northern Transdanubian companies operating in other regions too.

In the strengthening of the eastern bridgeheads of the automotive industry the process of expansion concentrated in space, with both quantitative and qualitative elements is realised. The location selection of the companies in the east is justified by the fact that new investments with employment growth are increasingly constrained in Northern Transdanubia due to the scarcity of human resources and, on the other hand, the development of transport and other infrastructure the number of potential locations for investments increase (Molnár, E. 2013). In Borsod-AbaújZemplén and Bács-Kiskun counties, however, the concentrated presence of automotive companies in the county seats (Miskolc and Kecskemét) is not unprecedented. Their accelerating embedding process, one of the most important fields of which (due to upgrading as well) is education supplying the human resources (JózsA, V. 2019), could hardly be met without the infrastructure and industrial traditions of their cities. For this reason, it is particularly true that for Bács-Kiskun county that its automotive industry is highly concentrated in its county seat. The fact that Daimler chose Kecskemét is not ground-breaking, considering that the city already had significant foreign capital (including the German automotive industry) at the turn of the millenni- 
Table 4. Major companies in the Hungarian automotive industry by the number of employees and county, 2008-2018

\begin{tabular}{|c|c|c|c|c|c|}
\hline \multirow{2}{*}{ Name of companies by counties } & \multirow{2}{*}{$\begin{array}{l}\text { Year of } \\
\text { foundation }\end{array}$} & \multicolumn{2}{|c|}{$\begin{array}{c}\text { Number of } \\
\text { employees (ca.) }\end{array}$} & \multirow{2}{*}{$\begin{array}{l}\text { Change in } \\
\text { employees in \% } \\
\text { of the county }\end{array}$} & \multirow{2}{*}{$\begin{array}{l}\text { Year of largest } \\
\text { employment }\end{array}$} \\
\hline & & 2008 & $2018^{*}$ & & \\
\hline $\begin{array}{l}\text { Győr-Moson-Sopron county } \\
\text { Audi Hungaria Motor Ltd. / Audi Hungaria Co. } \\
\text { SMR Automotive Mirror Technology Hungary Lp. } \\
\text { AUTOLIV Ltd. } \\
\text { BOS Automotive Products Magyarország Lp. } \\
\text { Rába Futómű Ltd. } \\
\text { Rába Járműalkatrész Ltd. }\end{array}$ & $\begin{array}{r}- \\
1993 \\
1993 \\
1990 \\
1992 \\
1999 \\
2001 \\
\end{array}$ & $\begin{array}{r}14,701 \\
5,939 \\
788 \\
942 \\
681 \\
1,415 \\
987\end{array}$ & $\begin{array}{r}25,279 \\
12,726 \\
2,549 \\
2,198 \\
1,128 \\
666 \\
598\end{array}$ & $\begin{array}{r}100 \\
64 \\
17 \\
12 \\
4 \\
-7 \\
-4\end{array}$ & $\begin{array}{l}- \\
2018 \\
2018 \\
2016 \\
2018 \\
2008 \\
2008\end{array}$ \\
\hline $\begin{array}{l}\text { Vas county } \\
\text { Schaeffler Savaria Ltd. } \\
\text { BPW Hungária Ltd. } \\
\text { GM Powertrain Ltd. / Opel Szentgotthárd Ltd. }\end{array}$ & $\begin{array}{c}- \\
1996 \\
1991 \\
1990\end{array}$ & $\begin{array}{r}5,64 \\
1220 \\
1259 \\
659\end{array}$ & $\begin{array}{l}8,974 \\
3485 \\
1518 \\
1007\end{array}$ & $\begin{array}{r}100 \\
63 \\
7 \\
10\end{array}$ & $\begin{array}{r}- \\
2018 \\
2018 \\
2017\end{array}$ \\
\hline $\begin{array}{l}\text { Veszprém county } \\
\text { Continental Automotive Hungary Ltd. } \\
\text { Johnson Controls / Yanfeng Hungary Ltd. } \\
\text { Valeo Auto-Electric Magyarország Ltd. } \\
\text { Johnson Controls / Adient Mezőlak Ltd. } \\
\text { Poppe + Potthoff Hungária Ltd. }\end{array}$ & $\begin{array}{c}- \\
1990 \\
2014 \\
1998 \\
2002 \\
1996 \\
\end{array}$ & $\begin{array}{r}4,513 \\
1,127 \\
-^{* *} \\
737 \\
265 \\
237 \\
\end{array}$ & $\begin{array}{r}11,386 \\
3,770 \\
2,345 \\
1,936 \\
874 \\
551 \\
\end{array}$ & $\begin{array}{r}100 \\
38 \\
34 \\
17 \\
9 \\
5\end{array}$ & $\begin{array}{l}- \\
2018 \\
2018 \\
2018 \\
2018 \\
2018\end{array}$ \\
\hline $\begin{array}{l}\text { Borsod-Abaúj-Zemplén county } \\
\text { Robert Bosch Energy and Body Systems Ltd. } \\
\text { S.E.G.A. Hungary Ltd. } \\
\text { Joyson Safety Systems Hungary Ltd. }\end{array}$ & $\begin{array}{r}- \\
2003 \\
2016 \\
2013\end{array}$ & $\begin{array}{r}3,457 \\
960 \\
0 \\
0\end{array}$ & $\begin{array}{l}9,237 \\
2,306 \\
1,601 \\
1,799\end{array}$ & $\begin{array}{r}100 \\
23 \\
28 \\
31 \\
\end{array}$ & $\begin{array}{r}- \\
2015 \\
2017 \\
2018\end{array}$ \\
\hline $\begin{array}{l}\text { Bács-Kiskun county } \\
\text { Mercedes Benz Manufacturing Hungary Ltd. } \\
\text { Knorr-Bremse Fékrendszerek Ltd. } \\
\text { Bosal / ACPS Automotive Ltd. } \\
\text { Magna / Antolin Hungary Ltd. }\end{array}$ & $\begin{array}{l}- \\
2008 \\
1989 \\
2003 \\
2010\end{array}$ & $\begin{array}{r}2,477 \\
0 \\
890 \\
154 \\
0\end{array}$ & $\begin{array}{r}9,142 \\
4,281 \\
1,011 \\
935 \\
604\end{array}$ & $\begin{array}{r}100 \\
64 \\
2 \\
12 \\
9\end{array}$ & $\begin{array}{c}- \\
2018 \\
2018 \\
2018 \\
2018\end{array}$ \\
\hline
\end{tabular}

*Motor vehicle companies with at least 500 employees in 2018. ** The factory of Johnson Controls at Pápa existed in 2008 as a unit of the company's subsidiary, thus its data is not involved in the data of Veszprém county. Source: County TOP 100 publications, ceginfo.hu, Ministry of Justice database of electronic reports.

um (Marsa, A. 2002). This was induced by a number of factors, such as its central location close to the agglomeration of Budapest, its transport capabilities and, consequently, the proximity of European and local suppliers, as well as its educational culture and technical higher education (VÁPÁr, J. 2013; SZEMEREYNÉ PATAKI, K. 2014).

The benefits of geographical proximity and the exploitation of industrial agglomeration indicate concentrated growth in space. Suppliers located near car factories played a significant role in the development of several industrial parks in Northern Transdanubia in the 2000s (Molnár, E. 2013). A similar phenomenon can be observed with Mercedes in Bács-Kiskun county, where the German car maker was followed by several companies (e.g. Brose, Magna/Antolin). The main driving force of the process is to reduce logistical costs and make deliveries flexible and safer.
Geographical proximity is especially important for large, components difficult to transport and also for just-in-time components. A good example is the factory "Kirchhoff" established close to the Suzuki's automobile factory in Esztergom, for which it manufactures car body parts. Like this is experienced at companies (e.g. Lear in Győr, Magyar Toyo Seat in Nyergesújfalu and Adient in Kecskemét) producing seat modules near car factories.

Geographical proximity can also cover relationships that go far beyond local dimensions. The experiences of a survey carried out by PriceWaterhouse Coopers (2018) on the final users of suppliers' products also proved this. According to their study the final users of the surveyed Hungarian suppliers' products are Volkswagen in 61 per cent, Audi in 56 per cent, Daimler in 51 per cent, BMW in 49 per cent, Renault in 42 per cent, Ford in 40 per cent, PSA in 37 per cent and Suzuki in 37 per cent. Merely 
19 per cent of companies sell only in Hungary, and only 7 per cent of those surveyed delivered within 50 kilometres and just over 15 per cent within $200 \mathrm{~km}$ (PriceWaterhouse Coopers, 2018). The positive impact of the automotive agglomeration in East-Central Europe on the growth of the Hungarian automotive industry is demonstrated, in addition to the above results, by that of Slovakia, directly adjacent to the counties of Northern Transdanubia, became the second largest market for engines and vehicle parts manufactured in Hungary, but Czechia, Poland and Austria are also ranked high (Table 5).

Counties with good quality indicators are the plants of car manufacturers near the peak of the supplier pyramids and also those of Tier 1 suppliers engaged in more complex activities. In counties that performed well almost continuously (Bács-Kiskun, Heves and Veszprém) the influence of one or two prominent Tier 1 suppliers with significant local value added can be recognised. These international companies were among the first to arrive to Hungary and largely built on local industrial traditions (Knorr-Bremse settled in Kecskemét utilised the heritage of the Tool Works, ZF from Eger based its activities on the transmission plant of the Csepel automobile factory, but former Bakony Works also had a history motor vehicle parts production in Veszprém). Significant functions apart from production can also be observed in these companies: e.g. R\&D (at Continental and Valeo in Veszprém, at Knorr-Bremse in Kecskemét, at ZF in Eger) or IT services (at $\mathrm{ZF}$ in Eger), often involving departments in Budapest too. In addition to their increasing non-manual worker employment rate, which is significantly above the average of the automotive industry, their relevant local supplier background should also be highlighted (Marsa, A. 2002; SAss, M. and SzANYI, M. 2004; JózsA, V. 2019). Not primarily the car assembly plants, but these companies producing greater local value added seem to be the real success stories of the FDI-based Hungarian automotive industry.

The ratio of non-manual workers in the automotive industry does not fully reflect the importance of non-production functions, as these activities may not be recorded for the motor vehicle industry. The best example for this is the R\&D in the automotive industry because many of companies (e.g. development bases of TNCs, Hungarian engineering offices, higher education - research institutions) taking part in it belong to the "official" motor vehicle industry only in a small ratio. The R\&D experts of the sector exist in greater numbers in the regions of Budapest and Győr. (The latter is the largest location of the Hungarian motor vehicle industry.) Several prominent automotive companies registered in the field of engineering activities, technical consulting, technical testing and analysis,

Table 5. TOP 10 market of the export of Hungarian motor vehicle industry, 2008-2018

\begin{tabular}{l|c|c|c|c}
\hline \multirow{2}{*}{ Country } & \multicolumn{2}{|c|}{$\begin{array}{c}\text { Export, } \\
\text { million EUR }\end{array}$} & $\begin{array}{c}\text { Change } \\
\text { 2008-2018, } \\
\text { million EUR }\end{array}$ & $\begin{array}{c}\text { Share of all export of } \\
\text { motor vehicle industry } \\
\text { in 2018, \% }\end{array}$ \\
\cline { 2 - 3 } Germany & 2008 & 2018 & 1,404 & 44.7 \\
Slovakia & 3,853 & 5,257 & 917 & 11.5 \\
Czechia & 431 & 1,348 & 145 & 5.7 \\
Spain & 528 & 674 & 149 & 4.9 \\
United Kingdom & 432 & 581 & 240 & 4.1 \\
Poland & 240 & 479 & 89 & 3.1 \\
Sweden & 275 & 363 & 311 & 3.1 \\
Austria & 49 & 359 & 133 & 3.0 \\
Mexico & 217 & 351 & 246 & 2.9 \\
France & 94 & 340 & 120 & 2.2 \\
\hline
\end{tabular}

*Internal combustion engines and their parts, and motor vehicle parts (current prices). Source: International Trade Centre. 
and research and development (e.g. Robert Bosch and Thyssenkrupp Components Technology or Trigo Quality Support and EDAG) operate there. Robert Bosch, the largest unit of automotive R\&D in Hungary, originally established as a sales and logistic centre, increased the number of its employees from nearly 600 to 3,000 between 2008 and 2018, and is now typically engaged in product and software development. Based on this, not only the role of Budapest in research and development will be enhanced, but the functions of Győr-Moson-Sopron beyond production will also be more visible.

Finally, supports granted on the basis of individual government decisions as part of the investment promotion policy also influence the spatiality of the industry. On the basis of data from ninety automotive investments registered not only in the motor vehicle industry in the narrow sense after 2008, it can be seen that, during the years of crisis and recovery, reduced investment has been concentrated in the old key areas of this sector (Table 6).

On the other hand, in contrast to the stability of the regional distribution of the sector between 2008 and 2018 - with the realisation of ongoing investments - an eastward shift is likely in the future. The largest growth in the Great Plain can be expected in Hajdú-Bihar county, which has been virtually absent from the map of the automotive industry, where, in addition to the BMW car assembly plant which is under construction and the attempt to establish local bus production, the concentrated occurrence and capacity expansion of several suppliers (Continental, Schaeffler, ThyssenKrupp) also play an important role in turning Debrecen into a centre of the Hungarian motor vehicle industry (Molnár, E. and Kozma, G. 2018).

\section{Conclusions}

The present study analysed the change in the geography of the significantly growing Hungarian automotive industry in the decade since the latest economic crisis in 2008. The overall increase in employment indicates that Hungary is still the target of capacity expansion. The spatially concentrated growth

Table 6. Financial supports and expected new workplaces in the Hungarian automotive industry by individual government decisions since 2008

\begin{tabular}{l|r|r|r|r}
\hline \multirow{2}{*}{ Regions, counties } & \multicolumn{2}{|c|}{ Share of all supports, $\%$} & \multicolumn{2}{c}{$\begin{array}{c}\text { Share of all expected } \\
\text { new workplaces, } \%\end{array}$} \\
\cline { 2 - 5 } & $2009-2013$ & $2014-2018$ & $2009-2013$ & $2014-2018$ \\
\hline Central Hungary & 13 & 2 & 27 & 3 \\
Budapest & 7 & 1 & 13 & 0 \\
Pest & 6 & 1 & 14 & 3 \\
Northern Transdanubia & 87 & 35 & 68 & 37 \\
Győr-Moson-Sopron & 45 & 12 & 31 & 11 \\
Vas & 16 & 0 & 12 & 0 \\
Komárom-Esztergom & 6 & 12 & 7 & 12 \\
Fejér & 20 & 3 & 17 & 3 \\
Veszprém & 0 & 8 & 0 & 10 \\
Northern Hungary & 0 & 28 & 0 & 27 \\
Borsod-Abaúj-Zemplén & 0 & 8 & 0 & 11 \\
Heves & 0 & 18 & 0 & 14 \\
Great Plain & 1 & 35 & 5 & 33 \\
Bács-Kiskun & 1 & 12 & 5 & 8 \\
Hajdú-Bihar & 0 & 10 & 0 & 7 \\
Jász-Nagykun-Szolnok & 0 & 8 & 0 & 9 \\
\hline Hungary total, \% & 100 & 100 & 100 & 100 \\
Hungary total in numbers & $141,664^{*}$ & $621,766^{*}$ & 6,997 & 20,327 \\
\hline * & & & \\
\hline
\end{tabular}

* In thousand EUR at price in 2018. Source: Ministry of Foreign Affairs. 
expected from the upgrading in the international production networks and the increase in the quality of industrial concentrations have been only partially achieved. The result of processes towards both concentration and expansion is characterised, on the one hand, by the massive growth of certain counties in Northern Transdanubia and, on the other hand, by the expansion of the industry concentrated in one or two new counties. This results in stability in the distribution of the automotive industry between regions. In terms of quality indicators, there is typically a difference between significant and less important locations and (above all) in terms of Budapest - outside Budapest. The present analysis indicates a moderate upgrading mostly without strategic functions, defined by foreign subsidiaries, and an industry that is gradually and selectively adapting the innovations of the "Fourth Industrial Revolution". Like other studies (Gerốcs, T. and Pinkasz, A. 2019; Szalavetz, A. and SoMosi, S. 2019; McKinsey \& Company 2020), the present analysis obtained no proof of a spectacular shift in the productive role of Hungary and in the grounds of its growth in automotive industrial networks. However, the example of the capital city points out that - in the case of appropriate local conditions - there is still some room for the implementation of functional upgrading, despite the dependent situation.

However, based on the last year data a trend change is emerging. After the maximum reached in the first quarter of 2019 for the first time in three consecutive quarters since the crisis - the number of people employed in the sector began to decrease, in almost all counties. In the background of the events general global economic developments and specific problems related to the competitiveness of the German automotive industry can be found (HAIDER, M. 2020). The large investment deferred in the second half of the year (Mercedes $2^{\text {nd }}$ phase in Kecskemét) also suggests this. Although the relocation of certain labour-intensive activities was observed during the 2008 crisis, structural constraints are now more pronounced in addition to economic fluctuations. Efficiency increase of production based on innovations of Industry 4.0 and the disruptive effects of electromobility (reduced number of employees in the Hungarian economy specialized partly on the production of internal combustion engines due to the spread of electric motors with less complexity) are mostly cited as explanations (FАво́к, B. and StuвnYA, B. 2019). To these conjunctural and structural problems the negative effects of the coronavirus pandemic can also be added in 2020 . The decreasing demand for cars, the disintegration of supply chains and the protection of employees can lead globally to the radical decrease of production (Rózsa, T. 2020). Its mid- and long-term consequences still cannot be foreseen. But significant changes are expected in the new decade which presumably also brings a new era in the history and geography of the Hungarian motor vehicle industry.

Acknowledgement: The research presented in this study was supported by the National Research Development and Innovation Office (project No.: K 125091) for which the authors hereby express their gratitude.

\section{REFERENCES}

Barta, Gy. 2002. A magyar ipar területi folyamatai 1945-2000 (Spatial processes of Hungarian industry 1945-2000). Budapest-Pécs, Dialóg Campus Kiadó.

Barta, Gy. 2012. Central and Eastern European automotive industry in European context. In Vehicle Industry and Competitiveness of Regions in Central and Eastern Europe. Eds.: Rechnitzer, J. and SMAhó, M., Győr, Universitas-Győr Nonprofit Kft., 33-70.

Boston Consulting Group 2015. Industry 4.0: The future of productivity and growth in manufacturing industries. Available at https://www.bcg.com/publications/2015/engineered_products_project_business_industry_4_future_productivity_growth_ manufacturing_industries.aspx

Coe, N.M., Hess, M., Yeung, H.W., Dicken, P. and Henderson, J. 2004. „Globalizing” regional development: a global production network perspective. Transactions of the Institute of British Geographers 29. (4): 468-484.

Coe, N.M. and Hess, M. 2011. Local and regional development. A global production network approach. 
In Handbook of Local and Regional Development. Eds.: Pike, A., Rodríguez-Pose, A. and Tomaney, J., London-New York, Routledge, 128-138.

Dicken, P. 2011. Global Shift. Mapping the Changing Contours of the World Economy. Los AngelesLondon-New Delhi-Singapore-Washington D.C., Sage.

Domański, B., Guzik, R., Gwosdz, K. and DeJ, M. 2013. The crisis and beyond: the dynamics and restructuring of automotive industry in Poland. International Journal of Automotive Technology and Management 13. (2): 151-166.

Éltető, A., Magasházi, A. and Szalavetz, A. 2015. Global value chains and upgrading: experiences of Hungarian firms in the machinery industry. Competitio 14. (1): 5-22.

Fаво́к, В. and SтuвnYa, В. 2019. Jelentős létszámcsökkentés az Audi győri gyárában, ezernél több ember távozhat (Significant decrease in the number of employees in the factory of Audi in Győr, more than thousand people can quit). Available at https://g7.hu/ vallalat/20191030/jelentos-letszamcsokkentes-azaudi-gyori-gyaraban-ezernel-tobb-ember-tavozhat/

FeKete, D. and Rechnitzer, J. 2019. Együtt nagyok. Város és vállalat 25 éve (Together great. 25 years of a town and a company). Budapest, Dialóg Campus Kiadó.

Gerócs, T. and Pinkasz, A. 2019. Relocation, standardization and vertical specialization: core - periphery relations in the European automotive value chain. Society and Economy 41. (2): 171-192.

Grosz, A. 2006. Clusterisation Processes in the Hungarian Automotive Industry. Pécs, Hungarian Academy of Sciences, Centre for Regional Studies.

Gwosdz, K. and Miceк, G. 2010. Spatial agglomerations in the Polish automotive industry. Przeglad Geograficzny 82. (2): 159-190.

Haider, M. 2020. Electrifying times: restructuring and decision-making in an automobile concern in the $21^{\text {st }}$ century - The case of BMW Group. Hungarian Geographical Bulletin 69. (2): 119-135.

HARDI, T. 2012. A közúti jármügyártás szerepe a keletközép- és délkelet-európai ipari térségek kialakulásában. In Jármüipar és regionális versenyképesség (Vehicle industry and regional competitiveness). Eds.: Rechnitzer, J. and Smahó, M., Győr, Széchenyi University Press, 99-108.

Humphrey, J. and Memedovic, O. 2003. The global automotive industry value chain: what prospects for upgrading by developing countries. Vienna, UNIDO.

Humphrey, J. and Schmitz, H. 2002. How does insertion in global value chains affect upgrading in industrial clusters? Regional Studies 36. (9): 1017-1027.

Józsa, V. 2019. A vállalati beágyazódás útjai Magyarországon (Ways of embedding of companies in Hungary). Budapest, Dialóg Campus Kiadó.

Jürgens, U. and Krzywdzinski, M. 2011. Die neue Ost-West-Arbeitsteilung. Frankfurt-New York, Campus Verlag.
Kaplinsky, R. 2013. Global value chains, where they came from, where they are going and why this is important. IKD Working Paper No. 68

KIss, É. 2002. A magyar ipar térszerkezeti változásai (Spatial structural changes of Hungarian industry). Földrajzi Értesítő / Hungarian Geographical Bulletin 51. (3-4): 347-364.

KIss, É. 2010. Területi szerkezetváltás a magyar iparban 1989 után (Spatial restructuring in Hungarian industry after 1989). Budapest-Pécs, Dialóg Campus Kiadó.

KIss, É. 2012. The impacts of the economic crisis on the spatial organisation of Hungarian industry. European Urban and Regional Studies 19. (1): 62-76.

KIss, É. and TINER, T. 2012. Depending on motorways - transport connections of Hungarian industrial parks and their enterprises. Hungarian Geographical Bulletin 61. (2): 131-153.

KSH 2016. A Magyarországon müködő külföldi irányítású leányvállalatok tevékenysége (2014. évi végleges és 2015. évi elözetes adatok alapján). (Activity of foreign subsidiaries controlling from abroad and operating in Hungary [based on the final data of 2014 and on the previous data of 2015]). Budapest, Központi Statisztikai Hivatal. Available at http://www.ksh. hu/docs/hun/xftp/idoszaki/pdf/kulfleany14.pdf

LengYel, I., SzAKálné KANó, I., VAs, Zs. and Lengyel, B. 2016. Az újraiparosodás térbeli kérdőjelei Magyarországon (Territorial questions of reindustrialization in Hungary). Közgazdasági Szemle 63. (6): 615-646.

Lengyel, I. and VARGA, A. 2018. A magyar gazdasági növekedés térbeli korlátai - helyzetkép és alapvető dilemmák (The spatial limits of economic growth in Hungary - an overview and some dilemmas). Közgazdasági Szemle 65. (5): 499-524.

Losonci, D., TAKács, O. and Demeter, K. 2019. Az ipar 4.0 hatásainak nyomában - a magyarországi jármüipar elemzése (After the effects of Industry $4.0-$ an analysis of the Hungarian vehicle industry). Közgazdasági Szemle 66. (2): 185-218.

Lux, G. 2017. Újraiparosodás Közép-Európában (Reindustrialization in Central Europe). BudapestPécs, Dialóg Campus Kiadó.

MAGE 2020. Magyarország jármüipara (Automotive industry of Hungary). Budapest, Magyar Gépjárműipari Egyesület. Available at https:// mage.org.hu/jarmuipar/

Marsa, A. 2002. Kecskemét, a Dél-Alföld „,kistigrise” és a külföldi működőtőke-beruházások, I-II. (Kecskemét, „the small-tiger" of the South-Plain and the foreign working capital-investments, I-II). Külgazdaság 46. (5-6): 53-75, 59-73.

McKinsey \& Company 2020. Rethinking European Automotive Competitiveness. The RED CEE opportunity. Available at https://www.mckinsey.com/ industries/automotive-and-assembly/our-insights/ 
rethinking-european-automotive-competitivenessthe-r-and-d-cee-opportunity

Molnár, E. 2013. Egy dinamikus iparág foglalkoztatási hatásainak földrajzi aspektusai: a magyarországi autóipar esete (Geographical aspects of employment impacts of a dynamic industry: the case of Hungarian automotive industry). Területi Statisztika 53. (4): 322-339.

Molnár, E., Kozma, G. and Pénzes, J. 2015. The intraregional trade relations in the automotive industry of East-Central Europe. Geografie 120. (3): 297-313.

Molnár, E. and Kozma, G. 2018. A debreceni gazdaságfejlesztés zászlóshajói: a városban működő ipari parkok jellegzetességei (Flagships of economic development of Debrecen: characteristics of industrial parks in the city). Tér és Társadalom 33. (3): 49-71.

Nagy, Cs., Molnár, E. and Kiss, É. 2020. Industry 4.0 in a dualistic manufacturing sector - qualitative experiences from enterprises and their environment, Eastern Hungary. Hungarian Geographical Bulletin 69. (2): 157-174.

Nemes Nagy, J. and Lőcsei, H. 2015. Hosszú távú megyei ipari növekedési pályák (1964-2013) (Longterm industrial growth trends by county [19642013]). Területi Statisztika 55. (2): 100-121.

Nick, G., VÁrgedő, T., Nagy, Cs. and Szaller, Á. 2019. The territorial contexts of industry 4.0 in Hungary, the present and future challenges and expectations of the digital ecosystem. Deturope 11. (3): 29-58.

Pavlínek, P. and Janák, L. 2007. Regional restructuring of the Skoda Auto supplier network in the Czech Republic. European Urban and Regional Studies 14. (2): 133-155.

Pavlínek, P., Domański, B. and Guzik, R. 2009. Industrial upgrading through foreign direct investment in Central European automotive manufacturing. European Urban and Regional Studies 16. (1): 43-63.

Pavlínek, P. Aláez-Aller, R. Gil-Canaleta, C. and Ullibarri-Arce, M. 2017. Foreign Direct Investment and the development of the automotive industry in Eastern and Southern Europe. Working Paper 2017.03. Brussels, European Trade Union Institute.

PAvlínek, P. 2018. Global production networks, foreign direct investment, and supplier linkages in the integrated peripheries of the automotive industry. Economic Geography 94. (2): 141-165.

Peters, S., Chun, J.H. and Lanza, G. 2016. Digitalization of automotive industry - scenarios for future manufacturing. Manufacturing Review 3. (1): 1-8.

Pénzügyminisztérium 2019. Összefoglaló a munkaerőkölcsönzők 2018. évi tevékenységéről (Summary on the activity of the services for labour hire for 2018). Available at https://nfsz.munka.hu/Lapok/ full_afsz_kozos_statisztika/stat_osszefogl_munkaero-kolcson_tevekeny/content/stat_osszefogl_ munkaero-kolcson_tevekeny_2018.pdf
PriceWaterhouse Coopers 2018. Magyarországi Autóipari Beszállítói Felmérés (Survey among Suppliers of Automotive Industry in Hungary). Available at https://www.pwc.com/hu/hu/kiadvanyok/assets/ pdf/automotive_survey_2018.pdf

Rózsa, T. 2020. A koronavírus nehéz helyzetbe hozza a magyar autóipart. A BMW-gyár megépülése éveket csúszhat (Due to COVID-19 pandemic the Hungarian automotive industry gets into difficult situation. The construction of BMW factory will delay several years). Available at https://www. portfolio.hu/gazdasag/20200412/a-koronavirusnehez-helyzetbe-hozza-a-magyar-autoipart-abmw-gyar-megepulese-eveket-csuszhat-425296

SAss, M. and SzAnYI, M. 2004. A hazai cégek és a multinacionális vállalatok közötti beszállítói kapcsolatok alakulása (The development of supplier linkages of local firms to multinational corporations). Külgazdaság 48. (9): 4-22.

Sснамр, E.W. 2005. Die Autoindustrie auf dem Weg nach Europa. Zur Integration nationaler Standortsysteme der Autoproduktion. Geographische Rundschau 57. (12): 12-19.

Sturgeon, T., van Biesebroeck, J. and Gereffi, G. 2008. Value chains, networks and clusters: reframing the global automotive industry. Journal of Economic Geography 8. (3): 297-321.

Szalavetz, A. 2016. Egy előre bejelentett forradalom krónikája Magyarországon - Ipar 4.0-technológiák és a hazai feldolgozóipari leányvállalatok (Chronicle of a revolution foretold in Hungary - Industry 4.0 technologies and manufacturing subsidiaries). Külgazdaság 60. (9-10): 28-48.

Szalavetz, A. 2019. Digitalization, automation and upgrading in global value chains - factory economy actors, versus lead companies. Post-Communist Economies 31. (5): 646-670.

Szalavetz, A. and Somosi, S. 2019. Ipar 4.0-technológiák és a magyarországi fejlődés-felzárkózás hajtóerőinek megváltozása - gazdaságpolitikai tanulságok (Impact of industry 4.0 technologies on the engines of development and catch-up in Hungary - some lessons for economic policy). Külgazdaság 63. (3-4): 66-93.

Szemereyné Pataki, K. 2014. Kecskemét ipari központtá fejlődésének mérföldkövei (Milestones of Kecskemét's development as an industrial centre). Polgári Szemle 10. (1-2): Available at https://polgariszemle.hu/archivum/84-2014marcius-10-evfolyam-1-2-szam/magyarorszagjobban-teljesit/579-kecskemet-ipari-koezponttafejlodesenek-merfoeldkoevei

SzÉKELY, S. 2019. Özönlenek a külföldi munkavállalók Magyarországra (Streaming foreign labour to Hungary). Available at https://privatbankar.hu/ makro/ozonlenek-a-kulfoldi-munkavallalokmagyarorszagra-328494 
Tóth, I.J., Nábelek, F. and Sturcz, A. 2016. Az automatizáció munkaerő-piaci hatásai. Járási munkaerő-piacok automatizációs kitettségének becslése (The labour market impacts of automation. Estimations of regional districts' labour markets affected by automation). Kutatási Füzetek 4. Budapest, MKIK GVI.

TúRY, G. 2017. Technológiai és munkaszervezési újitások hatása az au tóipar térbeli szervezódésére-iparági példa a Volkswagen mintáján (The impacts of technology and work organization innovations on the automotive industry's spatial structure - empirical evidence from Volkswagen). Tér és Társadalom 31. (2): 44-67.
VÁpÁr, J. 2013. A német müködőtőke-befektetések Magyarországon (German direct investments in Hungary). Tér és Társadalom 27. (1): 129-144.

Yeung, H.W. and Coe, N.M. 2015. Toward a dynamic theory of global production networks. Economic Geography 91. (1): 29-58.

YIN, Y., STECKE, K.E. and LI, D. 2018. The evolution of production systems from Industry 2.0 through Industry 4.0. International Journal of Production Research 56. (1-2): 848-861. 
